\title{
Remediation of degraded arable steppe soils in Moldova using vetch as green manure
}

\author{
M. Wiesmeier ${ }^{1}$, M. Lungu ${ }^{2}$, R. Hübner ${ }^{3}$, and V. Cerbari ${ }^{2}$ \\ ${ }^{1}$ Lehrstuhl für Bodenkunde, Wissenschaftszentrum Weihenstephan für Ernährung, Landnutzung und Umwelt, \\ Technische Universität München, 85350 Freising-Weihenstephan, Germany \\ ${ }^{2}$ Institute for Pedology, Agrochemistry and Soil Protection "Nicolae Dimo", Chisinau, Moldova \\ ${ }^{3}$ Chair for Strategic Landscape Planning and Management, Center of Life and Food Sciences \\ Weihenstephan, Technische Universität München, 85350 Freising-Weihenstephan, Germany \\ Correspondence to: M. Wiesmeier (wiesmeier@wzw.tum.de)
}

Received: 12 January 2015 - Published in Solid Earth Discuss.: 30 January 2015

Revised: 8 April 2015 - Accepted: 24 April 2015 - Published: 29 May 2015

\begin{abstract}
In the Republic of Moldova, non-sustainable arable farming led to severe degradation and erosion of fertile steppe soils (Chernozems). As a result, the Chernozems lost about $40 \%$ of their initial amounts of soil organic carbon (SOC). The aim of this study was to remediate degraded arable soils and promote carbon sequestration by implementation of cover cropping and green manuring in Moldova. Thereby, the suitability of the legume hairy vetch (Vicia sativa) as cover crop under the dry continental climate of Moldova was examined. At two experimental sites, the effect of cover cropping on chemical and physical soil properties as well as on yields of subsequent main crops was determined. The results showed a significant increase of SOC after incorporation of hairy vetch mainly due to increases of aggregateoccluded and mineral-associated OC. This was related to a high above- and belowground biomass production of hairy vetch associated with a high input of carbon and nitrogen into arable soils. A calculation of SOC stocks based on equivalent soil masses revealed a sequestration of around $3 \mathrm{tCha}^{-1} \mathrm{yr}^{-1}$ as a result of hairy vetch cover cropping. The buildup of SOC was associated with an improvement of the soil structure as indicated by a distinct decrease of bulk density and a relative increase of macroaggregates at the expense of microaggregates and clods. As a result, yields of subsequent main crops increased by around $20 \%$. Our results indicated that hairy vetch is a promising cover crop to remediate degraded steppe soils, control soil erosion and sequester substantial amounts of atmospheric $\mathrm{C}$ in arable soils of Moldova.
\end{abstract}

\section{Introduction}

In the Republic of Moldova, located at the western edge of the Eurasian steppe belt, about $80 \%$ of the land area is covered by Chernozems, which are thick, dark steppe soils. These soils are characterized by an exceptionally high amount of soil organic matter (SOM) and belong to the most fertile soils of the world. Due to their naturally high productivity, Chernozems were intensively used for agricultural production in Moldova since the end of the 19th century. Nonsustainable arable farming, particularly after the collapse of the Soviet Union, resulted in a severe degradation of these sensitive soils which was associated with a deterioration of the soil structure, compaction of the plough layer and erosion of the topsoil (Krupenikov et al., 2011). Today, almost $40 \%$ of agricultural land is eroded and 26 million tonnes of soil are lost every year (Andries et al., 2014; Kuharuk and Crivova, 2014). As a result, Chernozems lost approximately $40 \%$ of their initial amount of SOM, resulting in a strong decline of soil fertility and agricultural productivity (Krupenikov et al., 2011). Since the end of the 1980s crop yields of Moldova have been declining, which has caused economic losses of up to USD 260 million annually, not including environmental damages (Boincean, 2014; Kuharuk and Crivova, 2014). The detrimental effect of soil degradation might be aggravated by climate change, as mean annual temperature in Moldova has increased by $1.4^{\circ} \mathrm{C}$ since 1970 (Vronskih, 2014). This could have contributed to the decline of agricultural productivity because summer temperatures are already beyond the 
optimum of most crops, the probability of droughts has increased and the mineralization of SOM may be accelerated (Eitzinger et al., 2013; Supit et al., 2010; Trnka et al., 2012).

In order to restore fertility and productivity of Moldova's Chernozems, a sustainable way of arable farming primarily aimed at erosion control and the build up of SOM is needed. Several approaches were proposed to remediate degraded dryland soils worldwide (Garcia-Orenes et al., 2012; Wiesmeier et al., 2012a; Novara et al., 2011). A promising option is thereby an introduction of cover crops, particularly leguminous plants, for green manuring. Cover crops are frequently used in regions with sufficient precipitation in order to avoid soil erosion, control weeds, increase water infiltration, improve soil physical, chemical and biological properties, promote the formation of SOM and thus $\mathrm{C}$ sequestration and, last but not least, increase agricultural production (Dabney et al., 2001; Cherr et al., 2006; Fageria, 2005, 2007; Bronick and Lal, 2005; Poeplau and Don, 2015). In particular, legumes are used which additionally fix substantial amounts of atmospheric nitrogen $(\mathrm{N})$. However, under a dry continental climate as in Moldova, experience with cover crops is limited. It was hypothesized that in regions with low precipitation $\left(<500 \mathrm{~mm} \mathrm{yr}^{-1}\right)$, cover crops could have an adverse effect on agricultural productivity as the water available for subsequent main crops may be reduced (Blanco-Canqui et al., 2011; Stavi and Lal, 2013; Wortman et al., 2012; Unger and Vigil, 1998; Cherr et al., 2006).

In this study, the suitability of the legume hairy vetch ( $\mathrm{Vi}$ cia villosa) as cover crop was investigated under the dry continental climate in Moldova. Hairy vetch is known as a highyielding cover crop in temperate regions with a high potential for $\mathrm{N}$ fixation (Brandsaeter et al., 2008; Mirsky et al., 2012; Teasdale et al., 2004; Clark, 2007). Greenhouse experiments on the physiological response of the relative common vetch (Vicia sativa) to drought indicated that common and hairy vetch could be also useful in drylands (Tenopala et al., 2012). At two experimental sites in central and southern Moldova, mixtures of hairy vetch and winter wheat were sown which may be more advantageous than legume monocultures due to a more effective weed control, an increased biomass production, a decreased $\mathrm{N}$ leaching as well as an increased $\mathrm{N}$ availability for subsequent main crops (Sainju et al., 2002, 2005a; Mirsky et al., 2012; Dabney et al., 2010; Tosti et al., 2014). The main objectives of this study were to

- evaluate the productivity and the $\mathrm{N}$ fixing potential of hairy vetch under continental climatic conditions of Moldova,

- investigate the effect of cover cropping and green manuring on the physical and chemical quality of degraded arable Chernozems, and

- estimate the potential for an enhancement of $\mathrm{C}$ sequestration and agricultural productivity.

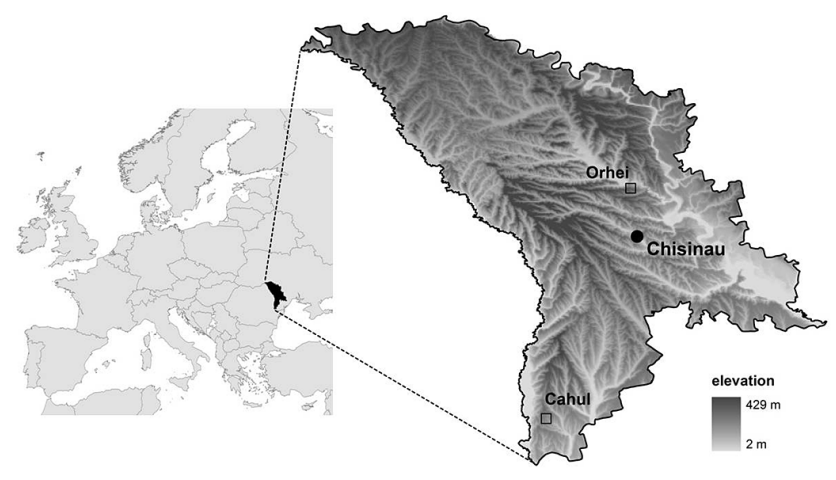

Figure 1. Topographic map of the Republic of Moldova showing the location of the study sites in the districts of Cahul and Orhei.

\section{Materials and methods}

\subsection{Study sites and experimental design}

The study was performed at two experimental sites in southern Moldova in the Cahul district next to the village of Lebedenko ( $28^{\circ} 19^{\prime} \mathrm{E}, 45^{\circ} 51^{\prime} \mathrm{N}, 165 \mathrm{~m}$ a.s.l. $)$ and in the in the central part of Moldova within the Orhei district in the vicinity of Ivancea village ( $28^{\circ} 53^{\prime} \mathrm{E}, 47^{\circ} 18^{\prime} \mathrm{N}, 173 \mathrm{~m}$ a.s.l.) (Fig. 1). The continental climate follows a north-south gradient with ranges of mean annual temperature from 7.5 to $10.5^{\circ} \mathrm{C}$ and of mean annual precipitation from 550 to $380 \mathrm{~mm}$ from north to south. Summer droughts occur frequently, particularly in the south. The soils were classified as Calcic Chernozem at the Cahul site and Haplic Chernozem at the Orhei site, both derived from loess (IUSS Working Group WRB, 2006). Soils of both experimental sites were intensively used for agricultural production for several decades. In September 2010 (Orhei) and September 2012 (Cahul), a mixture of $80 \%$ hairy vetch and $20 \%$ winter wheat (Triticum aestivum), referred to as HVW, was sown at two experimental plots with a size of 1 ha at each study site. In April 2011 (Orhei) and 2013 (Cahul), HVW was incorporated into the soil to a depth of $15 \mathrm{~cm}$ using a disk harrow. As subsequent main crops, sunflower (Helianthus annuиs) in Orhei and corn (Zea mays) in Cahul were grown and harvested in September 2011 and 2013, respectively. Before the start of the experiment and again before sowing the main crops, a fertilizer rate of $17 \mathrm{~kg} \mathrm{ha}^{-1} \mathrm{~N}$ was applied. Topsoil horizons (Ahp1, 0 to $12 \mathrm{~cm}$ depth; Ahp2, 12 to $20 \mathrm{~cm}$; Ahp3, 20 to $35 \mathrm{~cm}$; $\mathrm{Ah}$, 35 to $47 \mathrm{~cm}$ ) were sampled using steel cylinders with a volume of $100 \mathrm{~cm}^{3}$ before the start of the experiment and again after harvesting the basic crops at five locations from each experimental plot as well as adjacent control plots with similar soil conditions, where the same main crops were grown without previous HVW cover cropping. 


\subsection{Determination of soil properties and crop biomass}

Several physical and chemical soil properties were determined in order to characterize the soil status before and after the experiment. Soil texture was analyzed using the pipette method according to Gee et al. (1986). Bulk density (BD) was quantified from the mass of the oven-dry soil $\left(105^{\circ} \mathrm{C}\right)$ divided by the volume of the soil cores. The proportions of microaggregates $(<0.25 \mathrm{~mm})$, macroaggregates $(0.25-10 \mathrm{~mm})$ and clods $(>10 \mathrm{~mm})$ were quantified by dry sieving (Sainju, 2006). Total N content was determined by the Kjeldahl method (Bremner, 1996) and soil $\mathrm{pH}$ was measured in $\mathrm{H}_{2} \mathrm{O}$. The content of SOM was determined by wet oxidation and divided by the factor 1.724 in order to obtain soil organic carbon (SOC) contents (Nelson and Sommers, 1996). SOC stocks were calculated on the basis of an equivalent soil mass (ESM) approach according to Ellert and Bettany (1995). As green manuring is often associated with a change of $\mathrm{BD}$, constant investigation depths would result in a consideration of different soil masses for the quantification of SOC stocks. Thus, the investigation of the effect of cover cropping on SOC stocks has to be based on ESM (Post et al., 2001; Ellert and Bettany, 1995). For all topsoil horizons, soil masses of HVW plots as well as soil masses of control plots were calculated after HVW incorporation and harvest of the subsequent main crop. The differences of soil masses were used to derive corrected depths of topsoil horizons, which are necessary to obtain ESM. Total topsoil SOC stocks were calculated on the basis of ESM using corrected (initial SOC stocks) and unchanged (SOC stocks after HVW) horizon depths (Wiesmeier et al., 2015):

$\operatorname{SOC}_{h_{z}}=\sum_{i}^{h_{z}} \mathrm{SOC}_{i} \cdot \mathrm{BD}_{i} \cdot h_{i}$

where $\mathrm{SOC}_{h_{z}}$ is the total SOC stock $\left(\mathrm{kg} \mathrm{m}^{-2}\right)$ of all topsoil horizons $h_{z}, \mathrm{SOC}_{i}$ is the $\mathrm{SOC}$ concentration $\left(\mathrm{mg} \mathrm{g}^{-1}\right)$ of the fine earth of horizon $i, \mathrm{BD}_{i}$ is the $\mathrm{BD}\left(\mathrm{g} \mathrm{cm}^{-3}\right)$ of the fine earth of horizon $i$ and $h_{i}$ is the corrected/unchanged thickness $(\mathrm{cm})$ of horizon $i$.

In order to further characterize SOC quality, soil samples (0 to $12 \mathrm{~cm}$ depth) were fractionated to four classes: free particulate organic matter $(f \mathrm{POM})$, occluded POM within aggregates $(o \mathrm{POM})$, coarse mineral-associated organic matter $(\mathrm{MOM}>20 \mu \mathrm{m})$ and fine mineral-associated organic matter $(\mathrm{MOM}<20 \mu \mathrm{m})$, referred to as the fine fraction. Bulk soil samples $(<2 \mathrm{~mm}, 30 \mathrm{~g})$ were placed in a crystallization beaker and saturated with $150 \mathrm{~mL}$ sodium polytungstate solution with a density of $1.8 \mathrm{~g} \mathrm{~cm}^{-3}$. For the separation of $f$ POM the suspension was left to sit for 24 hours. Afterwards, $f$ POM was siphoned from the surface using a vacuum pump. Aggregates in the remaining soil were destroyed by ultrasonication (Sonoplus HD 2200) with an energy input of $150 \mathrm{~J} \mathrm{~mL}^{-1}$ (Wiesmeier et al., 2012b; Steffens et al., 2009). With a subsequent density fractionation step (sodium

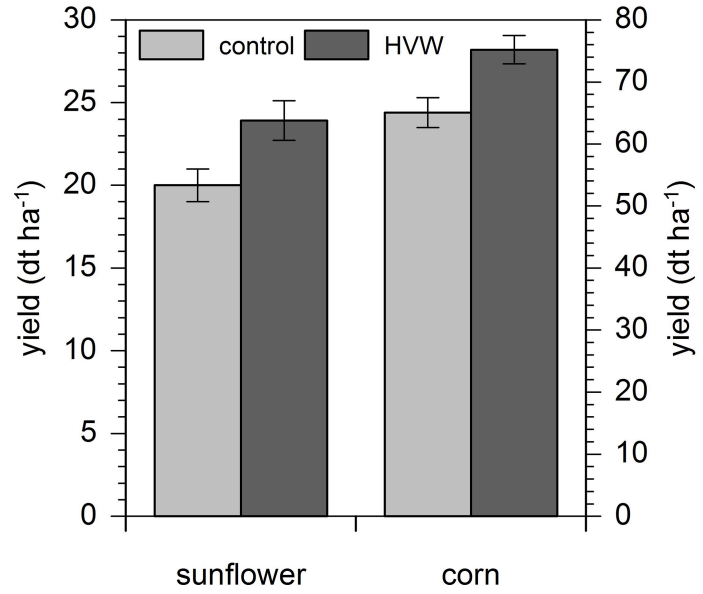

Figure 2. Yields of the main crops sunflower (in Orhei) and corn (in Cahul) on experimental fields after HVW intercropping and on control sites. Error bars represent standard deviation $(n=10)$.

polytungstate solution, $\rho=1.8 \mathrm{~g} \mathrm{~cm}^{-3}$ ), the $o$ POM floating on the suspension was obtained after centrifugation $(10 \mathrm{~min}$ at $4250 \mathrm{~g}$ ). Both $f \mathrm{POM}$ and $o \mathrm{POM}$ were washed with deionized water in a pressure filtration unit using $0.22 \mu \mathrm{m}$ filters to a salt concentration of $<2 \mu \mathrm{S}$. The remaining MOM was centrifuged (30 min at $4250 \mathrm{~g}$ ) and washed with deionized water several times in order to remove excessive salt $(<50 \mu \mathrm{S})$. Finally, the sample was wet sieved to $<20 \mu \mathrm{m}$ and all fractions were freeze-dried for $\mathrm{C}$ and $\mathrm{N}$ analysis. OC concentration in the four fractions was determined in duplicate by dry combustion on an EA3000 CN analyser (Hekatech, Wegberg, Germany). As all samples were free of carbonates, the measured $\mathrm{C}$ concentrations represent $\mathrm{OC}$ concentrations of the analyzed fractions.

Total aboveground biomass of hairy vetch was determined at five randomly selected locations within an area of $1 \mathrm{~m}^{2}$ at each experimental site. Root biomass was determined gravimetrically by washing soil monoliths (side length $15 \mathrm{~cm}$ ) to a depth of $35 \mathrm{~cm}$ within the selected locations. Yields of main crops were determined at five randomly selected locations of $6 \mathrm{~m}^{2}$ within control and experimental sites. The collected plant material was dried at $60^{\circ} \mathrm{C}$ for $24 \mathrm{~h}$ and yields were corrected for residual water at $105^{\circ} \mathrm{C}$. To test the significance of green manure effects on the examined parameters, Student's $t$ test were applied using the software IBM SPSS Statistics 19.

\section{Results}

\subsection{Hairy vetch biomass and main crop yields}

The above- and belowground biomass of hairy vetch as well as the related input of $\mathrm{C}$ and $\mathrm{N}$ is shown in Table 1. In total, dry masses of 7.2 and $8.0 \mathrm{tha}^{-1}$ were incorporated at Orhei 
Table 1. Dry masses (above- and belowground) of vetch and related input of $\mathrm{C}$ and $\mathrm{N}$ at Orhei and Cahul (mean values $\pm \mathrm{SD}, n=3$ ).

\begin{tabular}{llccccc}
\hline \multirow{2}{*}{ Study site } & & Dry mass & $\mathrm{C}$ & & $\mathrm{N}$ & N fixed \\
\cline { 3 - 4 } \cline { 7 - 7 } & & \multicolumn{2}{c}{$\left(\mathrm{tha}^{-1}\right)$} & & \multicolumn{2}{c}{$\left(\mathrm{kgha}^{-1}\right)$} \\
\hline \multirow{2}{*}{ Orhei } & aboveground & $5.2 \pm 0.2$ & $2.2 \pm 0.1$ & & $218 \pm 11$ & $174 \pm 9$ \\
& belowground & $2.0 \pm 0.3$ & $0.7 \pm 0.1$ & & $36 \pm 5$ & $29 \pm 4$ \\
\hline \multirow{2}{*}{ Cahul } & total & $7.2 \pm 0.5$ & $2.9 \pm 0.2$ & & $254 \pm 16$ & $203 \pm 13$ \\
& aboveground & $5.6 \pm 0.2$ & $2.2 \pm 0.1$ & & $230 \pm 12$ & $184 \pm 9$ \\
& belowground & $2.4 \pm 0.2$ & $0.9 \pm 0.1$ & & $43 \pm 4$ & $34 \pm 3$ \\
\hline & total & $8.0 \pm 0.4$ & $3.1 \pm 0.2$ & & $273 \pm 16$ & $218 \pm 12$ \\
\hline
\end{tabular}

*Assuming a mean proportion of $\mathrm{N}_{2}$ fixation on total $\mathrm{N}$ of $80 \%$ according to Rochester et al. (2005).

and Cahul, respectively, which was related to a total $\mathrm{C}$ input of 2.9 and $3.1 \mathrm{tha}^{-1}$. At both study sites, total $\mathrm{N}$ amounts of 254 and $273 \mathrm{~kg} \mathrm{ha}^{-1}$ were incorporated in which 203 and $218 \mathrm{~kg} \mathrm{ha}^{-1}(80 \%$ of total N) were biologically fixed according to Rochester et al. (2005). The incorporation of HVW as green manure showed a clear effect on the yields of the following main crops (Fig. 2). In Orhei, the yield of sunflower significantly $(P<0.05)$ increased by $22 \%$ compared to the control site. Similarly, corn yields significantly $(P<0.05)$ increased by $18 \%$ in Cahul.

\subsection{Physical soil properties}

The topsoils ( 0 to $47 \mathrm{~cm}$ ) of both study sites were characterized before the start of the experiment in terms of soil texture, $\mathrm{pH}$ and $\mathrm{C} / \mathrm{N}$ ratios (Table 2). In Orhei, topsoil horizons revealed high proportions of silt (55\%) and clay (37\%) and relatively low sand contents $(8 \%)$. Topsoils from Cahul showed comparable sand contents of $7 \%$ but higher proportions of silt $(65 \%)$ and lower contents of clay $(28 \%)$. The $\mathrm{pH}$ values were slightly higher in Cahul (7.0 to 7.3) compared to Orhei (6.5 to 6.6) and $\mathrm{C} / \mathrm{N}$ ratios of both study sites were in a close range of 8.9 to 9.8 .

After incorporation of one harvest of HVW and the subsequent main crop, a considerable improvement of physical soil parameters was observed at both study sites (Figs. 3 and 4). For BD, a significant $(P<0.05)$ decrease of 14 and $15 \%$ was detected for the Ahp1 (0 to $12 \mathrm{~cm})$ and of 4 and $9 \%$ for Ahp2 $(12$ to $20 \mathrm{~cm})$ at Orhei and Cahul, respectively. In Cahul, even BD of Ahp3 (20 to $35 \mathrm{~cm}$ ) decreased by $6 \%$. Further indication for an enhanced soil structure after HVW intercropping was found by analyzing the proportion of microaggregates $(<0.25 \mathrm{~mm})$, macroaggregates $(0.25$ to $10 \mathrm{~mm})$ and clods $(>10 \mathrm{~mm})$. At Orhei, a significant $(P<0.05)$ increase of macroaggregates by 6 to $8 \%$ was determined in the two upmost horizons. In Cahul, the macroaggregate content increased by $22 \%$ in both topsoil horizons and by $10 \%$ in the Ahp3. Accordingly, the relative proportion of clods and to a lower amount of microaggregates decreased.
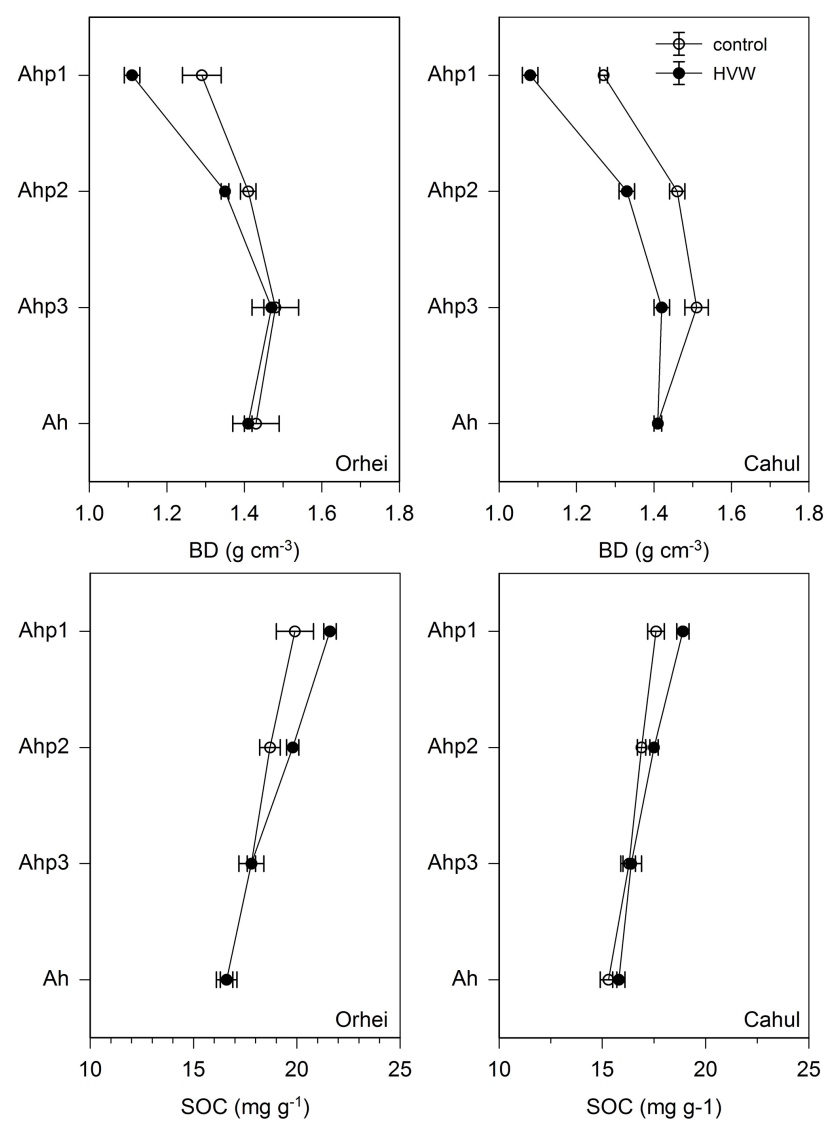

Figure 3. Bulk densities (BD) and soil organic carbon (SOC) contents of topsoil horizons of control and experimental sites in Orhei and Cahul after incorporation of HVW and harvest of the main crop. Error bars represent standard deviation $(n=10)$.

\subsection{Soil organic carbon stocks and fractions}

In addition to an enhanced soil structure, an increase of SOM was determined as a result of HVW cover cropping (Table 3, Fig. 3). At both study sites, SOC contents of Ahp1 and Ahp2 significantly $(P<0.05)$ increased by 7 to $9 \%$ and 4 
Table 2. Basic soil properties (soil texture, $\mathrm{pH}, \mathrm{C} / \mathrm{N}$ ratio) of topsoil horizons of experimental sites in Orhei and Cahul (mean values $\pm \mathrm{SD}$, $n=3$ ).

\begin{tabular}{lllllll}
\hline \multirow{2}{*}{ Study site } & Horizon & Sand $(\%)$ & Silt $(\%)$ & Clay $(\%)$ & $\mathrm{pH}\left(\mathrm{H}_{2} \mathrm{O}\right)$ & $\mathrm{C} / \mathrm{N}$ \\
\hline \multirow{2}{*}{ Orhei } & Ahp1 & $7.9 \pm 2.6$ & $55.5 \pm 4.4$ & $36.6 \pm 0.6$ & $6.6 \pm 0.2$ & $9.4 \pm 0.2$ \\
& Ahp2 & $7.8 \pm 1.9$ & $55.5 \pm 3.9$ & $36.7 \pm 0.6$ & $6.6 \pm 0.2$ & $9.2 \pm 0.2$ \\
& Ahp3 & $8.6 \pm 1.6$ & $54.7 \pm 2.9$ & $36.7 \pm 0.4$ & $6.5 \pm 0.1$ & $9.1 \pm 0.1$ \\
& Ah & $8.5 \pm 2.0$ & $54.6 \pm 4.3$ & $36.9 \pm 1.0$ & $6.6 \pm 0.1$ & $8.9 \pm 0.1$ \\
\hline \multirow{6}{*}{ Cahul } & Ahp1 & $7.1 \pm 0.6$ & $65.9 \pm 0.5$ & $27.1 \pm 0.2$ & $7.0 \pm 0.1$ & $9.6 \pm 0.7$ \\
& Ahp2 & $7.1 \pm 0.6$ & $65.8 \pm 0.5$ & $27.1 \pm 0.2$ & $7.0 \pm 0.2$ & $9.8 \pm 0.6$ \\
& Ahp3 & $7.3 \pm 0.4$ & $65.2 \pm 0.3$ & $27.5 \pm 0.1$ & $7.0 \pm 0.2$ & $9.8 \pm 0.4$ \\
& Ah & $7.3 \pm 0.6$ & $64.7 \pm 0.2$ & $28.3 \pm 0.2$ & $7.3 \pm 0.0$ & $9.7 \pm 0.6$ \\
\hline
\end{tabular}

Table 3. Soil masses and SOC stocks corrected for equivalent soil masses (ESM) of topsoil horizons of control and experimental sites in Orhei and Cahul after incorporation of HVW and harvest of the main crop (mean values $\pm \mathrm{SD}, n=10$ ).

\begin{tabular}{|c|c|c|c|c|c|c|}
\hline \multirow[t]{2}{*}{ Study site } & \multirow[t]{2}{*}{$\begin{array}{l}\text { Depth } \\
(\mathrm{cm})\end{array}$} & \multicolumn{2}{|c|}{$\begin{array}{l}\text { Soil mass } \\
\left(\mathrm{kg} \mathrm{m}^{-2}\right)\end{array}$} & \multirow[t]{2}{*}{$\begin{array}{l}\text { ESM depth correc- } \\
\text { tion }(\mathrm{cm})\end{array}$} & \multicolumn{2}{|c|}{$\begin{array}{l}\text { SOC stock } \\
\left(\mathrm{kg} \mathrm{m}^{-2}\right)\end{array}$} \\
\hline & & control & vetch & & control & vetch \\
\hline \multirow[t]{5}{*}{ Orhei } & Ahp1 & $155 \pm 6$ & $133 \pm 2$ & $2.0 \pm 0.2$ & $2.6 \pm 0.1$ & $2.8 \pm 0.1$ \\
\hline & Ahp2 & $113 \pm 2$ & $108 \pm 1$ & $0.4 \pm 0.1$ & $2.0 \pm 0.1$ & $2.1 \pm 0.0$ \\
\hline & Ahp3 & $222 \pm 9$ & $221 \pm 3$ & - & $3.9 \pm 0.1$ & $3.9 \pm 0.1$ \\
\hline & $\mathrm{Ah}$ & $172 \pm 7$ & $169 \pm 1$ & - & $2.8 \pm 0.1$ & $2.8 \pm 0.1$ \\
\hline & total & $661 \pm 24$ & $631 \pm 7$ & $2.3 \pm 0.3$ & $11.3 \pm 0.2$ & $11.6 \pm 0.1$ \\
\hline \multirow[t]{5}{*}{ Cahul } & Ahp1 & $153 \pm 1$ & $129 \pm 2$ & $1.9 \pm 0.1$ & $2.2 \pm 0.1$ & $2.4 \pm 0.1$ \\
\hline & Ahp2 & $117 \pm 2$ & $106 \pm 1$ & $0.8 \pm 0.2$ & $1.8 \pm 0.0$ & $1.9 \pm 0.0$ \\
\hline & Ahp3 & $226 \pm 4$ & $213 \pm 3$ & $1.0 \pm 0.4$ & $3.5 \pm 0.1$ & $3.5 \pm 0.1$ \\
\hline & $\mathrm{Ah}$ & $169 \pm 1$ & $169 \pm 1$ & - & $2.7 \pm 0.1$ & $2.7 \pm 0.0$ \\
\hline & total & $665 \pm 8$ & $618 \pm 7$ & $3.6 \pm 0.7$ & $10.2 \pm 0.3$ & $10.5 \pm 0.0$ \\
\hline
\end{tabular}

to $6 \%$, respectively. The associated decrease of $\mathrm{BD}$ required an ESM approach to quantify the effect of green manuring on SOC stocks (Table 3$)$. Due to significantly $(P<0.05)$ different soil masses in topsoil horizons at HVW and control sites, the depth for the calculation of total SOC stocks in the topsoil was corrected by $2.3 \mathrm{~cm}$ at Orhei and $3.6 \mathrm{~cm}$ at Cahul. SOC stocks based on ESM significantly $(P<0.05)$ increased from 11.3 to $11.6 \mathrm{~kg} \mathrm{~m}^{-2}$ at Orhei and from 10.2 to $10.5 \mathrm{~kg} \mathrm{~m}^{-2}$ at Cahul due to HVW incorporation. Thus, an amount of $3 \mathrm{tCha}^{-1} \mathrm{yr}^{-1}$ was sequestered in agricultural soils of Moldova as a result of HVW intercropping and green manuring.

The fractionation indicated an effect of HVW cover cropping on different soil fractions (Table 4, Fig. 5). In general, the fine fraction $<20 \mu \mathrm{m}$ contained the major part of OC (64 to $65 \%$ ), followed by the $o$ POM which contributed with 29 to $30 \%$ to total SOC. The OC contents of $f$ POM and MOM $>20 \mu \mathrm{m}$ were of minor importance ( 2 to $5 \%$ ). At both study sites, HVW intercropping resulted in a significant $(P<0.05)$ increase of $f$ POM-OC and fine fraction OC compared to control plots. For $o$ POM and MOM $>20 \mu \mathrm{m}$, OC contents tended also to increase but differences were not significant. The $\mathrm{C} / \mathrm{N}$ ratios of all separated fractions tended to decrease in topsoils under HVW intercropping compared to control plots.

\section{Discussion}

\subsection{Biomass of hairy vetch and $\mathrm{C}$ and $\mathrm{N}$ input}

The cultivation of hairy vetch as cover crop in Moldova revealed a relatively high above- and belowground biomass production and related $\mathrm{C}$ and $\mathrm{N}$ input into soils compared to results from other studies worldwide (Table 5). The aboveground biomass was 27 to $37 \%$ higher compared to the global average and belowground biomass was even twice as high. However, only a few studies investigated the root biomass of hairy vetch and the available results are hardly comparable due to different depths considered and general difficulties in root biomass determination. Remarkably, studies which applied mixtures of hairy vetch and cereals as in our study showed higher aboveground biomass similar to our 
Table 4. Organic carbon $(\mathrm{OC})$ and nitrogen $(\mathrm{N})$ concentrations and $\mathrm{C} / \mathrm{N}$ ratios of soil fractions ( $f \mathrm{POM}$ is free particulate organic matter; $o \mathrm{POM}$ is aggregate-occluded particulate organic matter; $\mathrm{MOM}>20 \mu \mathrm{m}$ is coarse mineral-associated organic matter; $\mathrm{MOM}<20 \mu \mathrm{m}$ is fine mineral-associated organic matter) in topsoils ( 0 to $12 \mathrm{~cm})$ of control and HVW sites.

\begin{tabular}{|c|c|c|c|c|c|}
\hline & & \multicolumn{2}{|c|}{ Cahul } & \multicolumn{2}{|c|}{ Orhei } \\
\hline & & control & HVW & control & HVW \\
\hline \multirow[t]{3}{*}{$f \mathrm{POM}$} & $\mathrm{OC}\left(\mathrm{mg} \mathrm{g}^{-1}\right)$ & $136.4 \pm 3.3$ & $142.0 \pm 10.1$ & $131.6 \pm 4.6$ & $134.7 \pm 2.3$ \\
\hline & $\mathrm{N}\left(\mathrm{mg} \mathrm{g}^{-1}\right)$ & $8.8 \pm 0.1$ & $9.6 \pm 0.4$ & $8.8 \pm 0.3$ & $9.3 \pm 0.2$ \\
\hline & $\mathrm{C} / \mathrm{N}$ & $15.5 \pm 0.2$ & $14.7 \pm 0.5$ & $15.0 \pm 0.1$ & $14.5 \pm 0.2$ \\
\hline \multirow[t]{3}{*}{$o \mathrm{POM}$} & $\mathrm{OC}\left(\mathrm{mg} \mathrm{g}^{-1}\right)$ & $336.9 \pm 1.8$ & $363.3 \pm 3.4$ & $343.5 \pm 3.3$ & $379.8 \pm 9.3$ \\
\hline & $\mathrm{N}\left(\mathrm{mg} \mathrm{g}^{-1}\right)$ & $19.2 \pm 0.8$ & $21.6 \pm 0.5$ & $18.2 \pm 0.4$ & $20.3 \pm 0.6$ \\
\hline & $\mathrm{C} / \mathrm{N}$ & $17.6 \pm 0.8$ & $16.8 \pm 0.2$ & $18.9 \pm 0.2$ & $18.7 \pm 0.1$ \\
\hline \multirow[t]{3}{*}{$\mathrm{MOM}>20 \mu \mathrm{m}$} & $\mathrm{OC}\left(\mathrm{mg} \mathrm{g}^{-1}\right)$ & $1.1 \pm 0.1$ & $1.2 \pm 0.0$ & $1.4 \pm 0.1$ & $1.5 \pm 0.2$ \\
\hline & $\mathrm{N}\left(\mathrm{mg} \mathrm{g}^{-1}\right)$ & $0.2 \pm 0.0$ & $0.2 \pm 0.0$ & $0.2 \pm 0.0$ & $0.2 \pm 0.0$ \\
\hline & $\mathrm{C} / \mathrm{N}$ & $6.1 \pm 0.8$ & $5.8 \pm 1.1$ & $7.6 \pm 1.5$ & $6.4 \pm 0.7$ \\
\hline \multirow[t]{3}{*}{$\mathrm{MOM}<20 \mu \mathrm{m}$} & $\mathrm{OC}\left(\mathrm{mg} \mathrm{g}^{-1}\right)$ & $18.7 \pm 0.1$ & $20.7 \pm 0.1$ & $19.2 \pm 0.4$ & $21.2 \pm 0.0$ \\
\hline & $\mathrm{N}\left(\mathrm{mg} \mathrm{g}^{-1}\right)$ & $2.1 \pm 0.1$ & $2.4 \pm 0.2$ & $2.1 \pm 0.0$ & $2.4 \pm 0.1$ \\
\hline & $\mathrm{C} / \mathrm{N}$ & $9.0 \pm 0.1$ & $8.7 \pm 0.1$ & $9.1 \pm 0.2$ & $8.8 \pm 0.3$ \\
\hline
\end{tabular}
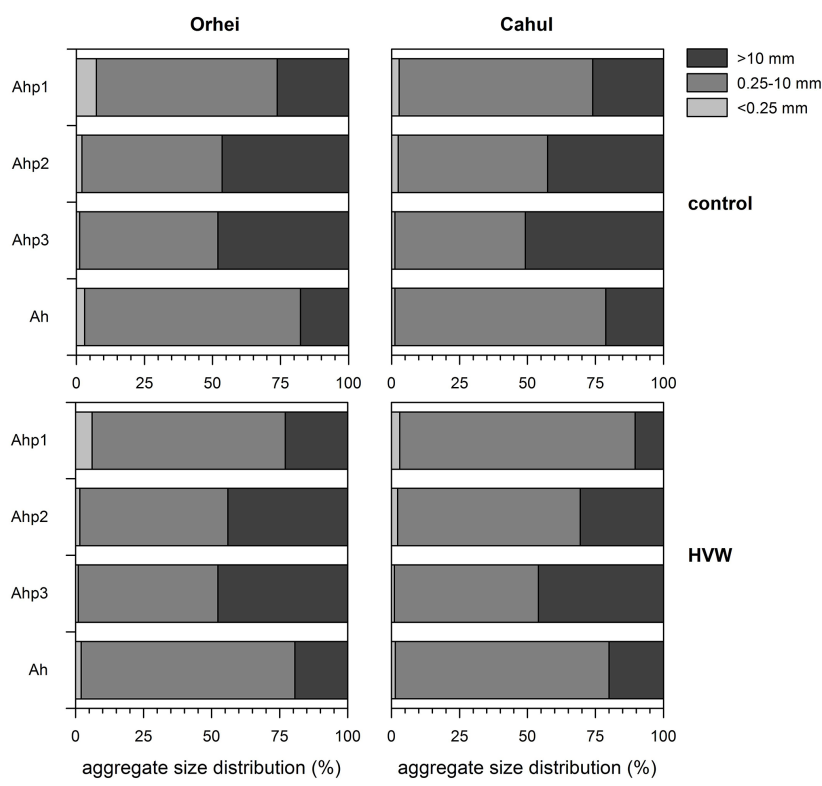

Figure 4. Distribution of microaggregates $(<0.25 \mathrm{~mm})$, macroaggregates $(0.25-10 \mathrm{~mm})$ and clods $(>10 \mathrm{~mm})$ in topsoil horizons of control and experimental sites in Orhei and Cahul after incorporation of HVW and harvest of the main crop.

results. This confirmed the assumption that hairy vetch/cereal mixtures are more effective than monocultures for green manuring, particularly in terms of the $\mathrm{C}$ input (Dabney et al., 2010; Mirsky et al., 2012; Sainju et al., 2002; Tosti et al., 2014). According to the higher biomass production, the total $\mathrm{C}$ input of hairy vetch was 45 to $55 \%$ higher compared to the average value from the literature. However, in the only study that investigated the $\mathrm{C}$ input of hairy vetch and a hairy vetch/rye mixture, the mixture revealed a substantially higher
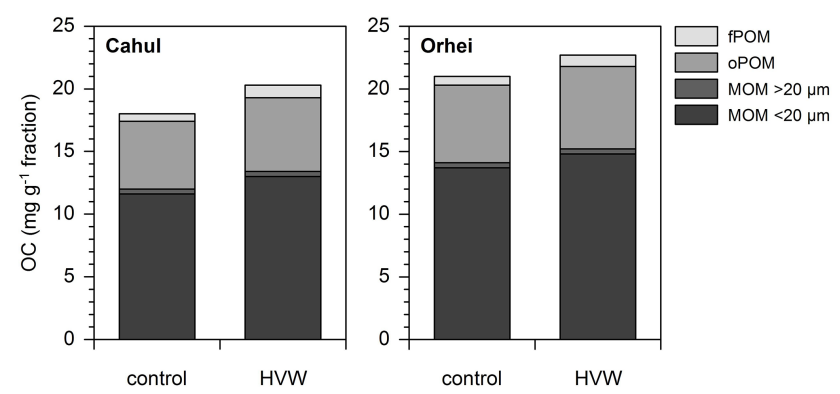

Figure 5. Organic carbon (OC) concentration of different soil fractions ( $f \mathrm{POM}$ is free particulate organic matter; $o \mathrm{POM}$ is aggregate-occluded particulate organic matter; $\mathrm{MOM}>20 \mu \mathrm{m}$ is coarse mineral-associated organic matter; $\mathrm{MOM}<20 \mu \mathrm{m}$ is fine mineral-associated organic matter) in topsoils (0 to $12 \mathrm{~cm})$ of control and HVW sites.

$\mathrm{C}$ input $(67 \%)$ in the range of our results, which can be attributed to the higher $\mathrm{C} / \mathrm{N}$ ratio of cereals compared to hairy vetch (Sainju et al., 2005a, b). This clearly demonstrates the advantage of hairy vetch/cereal mixtures for green manure approaches which are primarily aimed at increasing the amount of SOM in degraded soils and promoting $\mathrm{C}$ sequestration.

Furthermore, the detected $\mathrm{N}$ input of hairy vetch was distinctly higher than the global average. The aboveground $\mathrm{N}$ input was 56 to $64 \%$ higher than the global mean value and the belowground $\mathrm{N}$ input was almost 3 times higher. Interestingly, the difference between the average $\mathrm{N}$ input derived from literature data and our results was much higher than the difference in terms of the biomass, which points towards a higher $\mathrm{N}$ concentration of hairy vetch biomass in Moldova. In fact, the determined $\mathrm{N}$ concentration of 4.1 to $4.2 \%$ was higher than the mean $\mathrm{N}$ concentration of $3.5 \pm 0.7 \%$ esti- 


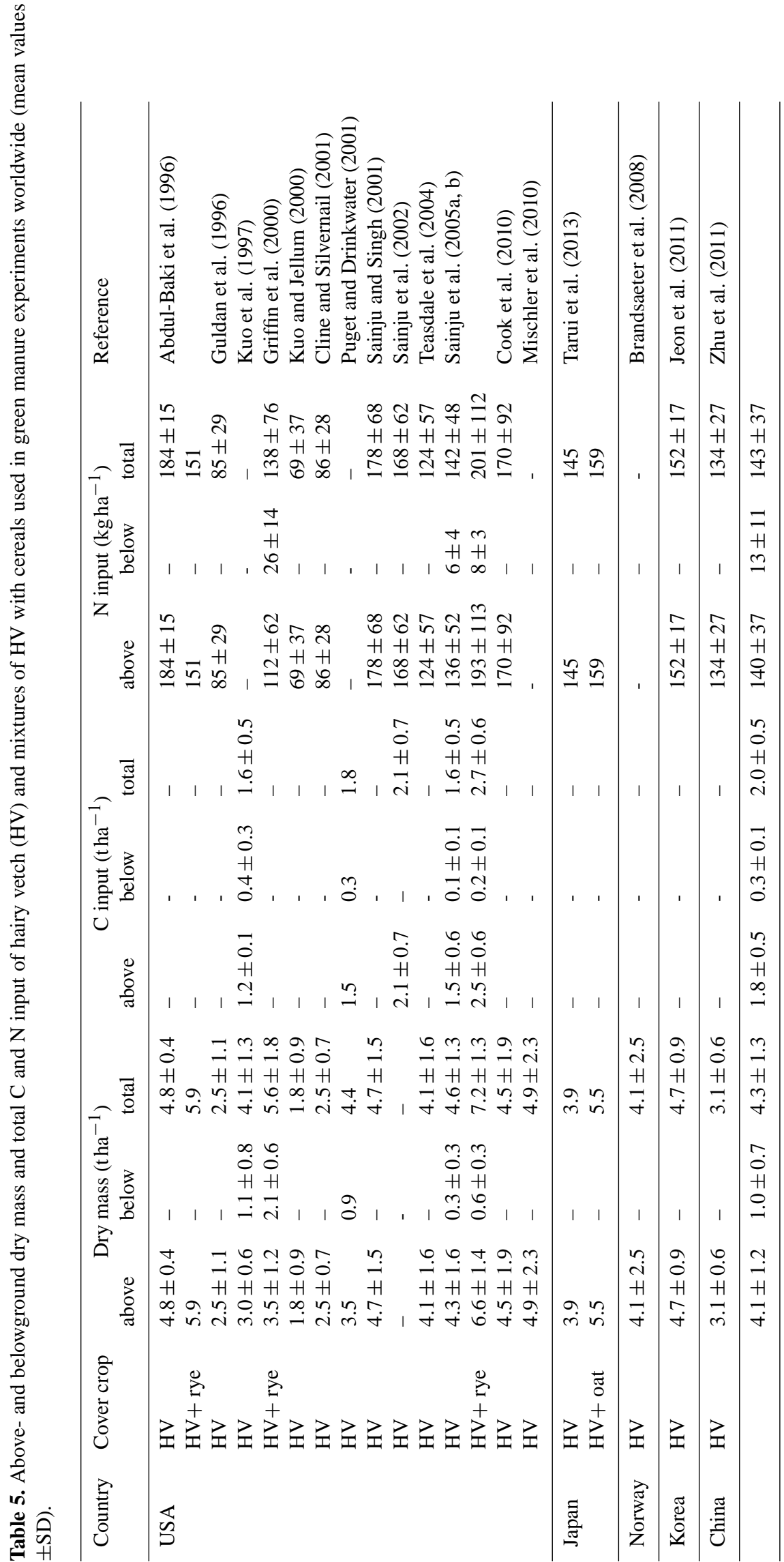


mated from data presented in Table 4. The effect of hairy vetch/cereal mixtures on the $\mathrm{N}$ input was not as pronounced as for the $\mathrm{C}$ input due to the high $\mathrm{C} / \mathrm{N}$ ratio of cereals.

\subsection{Increase of SOC and carbon sequestration potential}

The high above- and belowground biomass production of hairy vetch and the related high $\mathrm{C}$ input led to an increase of SOM even after incorporation of one harvest of HVW. A significant increase of SOC contents by 7 to $9 \%$ was found in the topsoil (Ahp1) of degraded arable soils mainly due to increases of OC contents of $f \mathrm{POM}$ and the fine fraction $<20 \mu \mathrm{m}$. Incorporation of hairy vetch as green manure in temperate region of the USA had a negligible effect after 1 year and similar increases of SOC occurred only after several years (Sainju et al., 2002; Kuo et al., 1997). However, C input by hairy vetch was distinctly lower (1.7 to $\left.2.5 \mathrm{tha}^{-1}\right)$ compared to our study. The calculation of SOC stocks based on ESM revealed an increase of 5 to $9 \%$ in upmost topsoil horizons (Ahp1 and Ahp2). Incorporation of one harvest of HVW resulted in a sequestration of $3 \mathrm{tCha}^{-1}$ in topsoils $(0$ to $20 \mathrm{~cm}$ ). This is in the upper part of the range of observed $\mathrm{C}$ sequestration rates in humid regions. In the USA, the incorporation of hairy vetch as green manure in cereal, cotton and vegetable production resulted in a wide range of SOC accumulation of 0.2 to $2.7 \mathrm{tha}^{-1} \mathrm{yr}^{-1}$ in topsoils $(0$ to $30 \mathrm{~cm}$ ) in the first 3 to 7 years of the experiments (Sainju et al., 2002, 2003, 2005b). In Japan, C sequestration ranges from 0.6 to $1.0 \mathrm{tha}^{-1} \mathrm{yr}^{-1}$ were found in topsoils $(0$ to $30 \mathrm{~cm})$ by including hairy vetch as cover crop in rice and soybean cultivation under a humid subtropical climate (Higashi et al., 2014). General estimations of $C$ sequestration rates in arable soils due to green manuring were also lower with a mean of $0.9 \pm 1.3 \mathrm{C} \mathrm{tha}^{-1} \mathrm{yr}^{-1}$ (Balkcom et al., 2013; Jarecki and Lal, 2003). The high variation of the effect of green manuring on SOC sequestration is related to several environmental and management factors. Besides growth conditions of cover crops (length of cultivation, soil status, climatic conditions), $\mathrm{N}$ fertilization rate and the way of tillage seems to be crucial for SOC accumulation. The relatively high amount of $\mathrm{C}$ that was sequestered in arable soils of Moldova may be attributed on the one hand to the high biomass production of hairy vetch and the related high $\mathrm{C}$ input into the soil.

On the other hand, the build up of SOC stocks largely depends on the $\mathrm{C}$ stabilization mechanisms of the soil and the associated storage capacity. In arable soils, the occlusion of SOM in soil aggregates and the interaction of SOM with mineral surfaces constitute the dominant stabilization mechanisms (von Lützow et al., 2006; Sollins et al., 1996). This was confirmed by the fraction approach that revealed a contribution of $\mathrm{OC}$ in the $o \mathrm{POM}$ and fine fraction of $>90 \%$. Hassink (1997) found evidence for a worldwide strong correlation of the $\mathrm{C}$ storage potential of arable soils with the proportion of silt and clay particles $<20 \mu \mathrm{m}$. As the studied steppe soils are characterized by exceptionally high proportions of silt and clay (>90\%), one can assume a high potential $\mathrm{C}$ storage capacity. In fact, early estimations in noncultivated Chernozems in Moldova at the end of the 19th century revealed SOC contents of 30 to $40 \mathrm{mg} \mathrm{g}^{-1}$ (Ursu et al., 2014). Due to the massive SOC loss of $40 \%$ induced by nonsustainable arable farming in the 20th century, there is presumably a high $\mathrm{C}$ saturation deficit and thus a high $\mathrm{C}$ storage capacity in degraded arable soils of Moldova (Krupenikov et al., 2011). On a country basis, approximately $3.1 \mathrm{MtC} \mathrm{yr}^{-1}$ could be sequestered in arable topsoils by green manuring over a period of 20 to 25 years. This amount corresponds to $11.4 \mathrm{Mt} \mathrm{CO}_{2}$ equivalents, which almost equals Moldova's annual greenhouse gas emissions of $11.9 \mathrm{MtCO}_{2}$ equivalents (in 2005).

\subsection{Improvement of soil structure}

The buildup of SOM induced by green manuring was associated with an improvement of soil structure. This was indicated by an increase of macroaggregates $(0.25$ to $10 \mathrm{~mm})$ at the expense of microaggregates $(<0.25 \mathrm{~mm})$ and clods $(>10 \mathrm{~mm})$. Generally, there is evidence for aggregate hierarchy in temperate soils: microaggregates $(<0.25 \mathrm{~mm})$ are bound together into macroaggregates $(>0.25 \mathrm{~mm})$ by organic binding agents like roots and hyphae (Oades, 1984; Tisdall and Oades, 1982; Six et al., 2004). As a result, macroaggregates are characterized by higher $\mathrm{C}$ contents compared to microaggregates (Gupta and Germida, 1988; Six et al., 2000). Intensive soil cultivation leads to a loss of C-rich macroaggregates and a concurrent increase of $\mathrm{C}$-depleted microaggregates (Six et al., 2000). Therefore, the proportion of macroaggregates, particularly the aggregate size class of 0.25 to $10 \mathrm{~mm}$, was proposed as suitable indicator for soil quality (Oades, 1984; Tisdall and Oades, 1982; Nichols and Toro, 2011). The cultivation of hairy vetch as cover crop apparently promoted the formation of macroaggregates due to an increased $\mathrm{C}$ input which probably stimulated microbial biomass and thus the formation of polymers that act as binding agents. Moreover, the increased root growth was presumably related to an enhanced enmeshing of microaggregates which directly promoted macroaggregate formation. Fractionation results also indicated an increased stabilization of OC within soil aggregates as a significant $(P<0.05)$ increase of $o \mathrm{POM}-\mathrm{OC}$ concentrations under HVW was detected. In a study that investigated the dynamics of root- and shoot-derived $\mathrm{C}$ from hairy vetch, it was concluded that rootderived $\mathrm{C}$ plays an important role in the formation of aggregates (Puget and Drinkwater, 2001). Increased proportions of macroaggregates and a decrease of microaggregates and clods were also reported in other studies in temperate regions which used hairy vetch as cover crop (Sainju et al., 2003; Blanco-Canqui et al., 2011). 
Besides improved (macro)aggregation, green manuring resulted also in a decreased compaction of the upmost topsoil horizons as it was indicated by decreased BD. The decrease of $\mathrm{BD}$ was considerably higher (14 to $15 \%$ ) compared to a reduction of BD by $7 \%$ induced by hairy vetch cover cropping in the USA, probably due to a higher accumulation of SOC in our study (Villamil et al., 2006). The improvement of soil structure in terms of enhanced aggregation and reduced soil compaction is not only related with a stabilization of SOC but concurrently leads to enhanced resistance to erosion, improved root growth of main crops and increased infiltration and water-holding capacity.

\subsection{Crop yields as affected by green manuring}

A substantial increase of main crop yields by around $20 \%$ in the subsequent year was detected after incorporation of one harvest of HVW into arable soils of Moldova. This yield increase can be attributed to the combined effect of a high $\mathrm{N}$ input, an accumulation of SOM and an improved soil structure that is associated with an enhanced availability of nutrients and, most importantly, water, which is the main limiting factor under the continental climatic conditions in Moldova. In contrast, a meta-analysis of the effect of cover crops on crop yields revealed a mean decrease of crop yields by $10 \%$ and similar yields compared to conventional cultivation when legume biomass provided $>110 \mathrm{~kg} \mathrm{Nha}^{-1}$ (Tonitto et al., 2006). However, only studies were incorporated in the metaanalysis which had no additional $\mathrm{N}$ fertilization. In studies that investigated the effect of hairy vetch on yields of subsequent crops, significant increases of yields were generally determined probably due to the exceptional high $\mathrm{N}$ input by hairy vetch compared to other legumes (Kuo and Jellum, 2000; Sainju et al., 2002, 2005a; Rochester and Peoples, 2005). Thus, the integration of hairy vetch as cover crop in Moldova is also advantageous from an economic point of view. The economic gain of a yield increase of around $1 \mathrm{tha}^{-1} \mathrm{yr}^{-1}$ grain units (USD 140) offsets the expenses for seeds, soil processing and preparation, sowing and incorporation of hairy vetch biomass into the soil (USD 110). This rough estimation does not account for savings in terms of reduced fertilizer application and environmental costs, e.g., expenses related with nitrate leaching and soil erosion.

\section{Conclusions}

Our results provided evidence that hairy vetch is a suitable cover crop under the continental climatic conditions of Moldova. A high above- and belowground biomass production was associated with a high input of $\mathrm{C}$ and $\mathrm{N}$ into arable soils, resulting in a significant increase of SOM already after incorporation of one harvest. Thus, green manuring using hairy vetch is an effective option to sequester atmospheric $\mathrm{C}$ in degraded arable soils of Moldova which have a high $\mathrm{C}$ sequestration potential. A countrywide implementation of green manuring on SOM-depleted soils could roughly compensate Moldova's annual greenhouse gas emissions in the next 20 to 25 years. The buildup of SOM was related with a substantial improvement of soil structure leading to enhanced resistance to erosion, improved root growth of main crops and probably increased infiltration and waterholding capacity. As a result, yields of subsequent main crops increased by $20 \%$. Green manuring with hairy vetch is a promising method to improve the economic situation of farmers and to control soil degradation in Moldova. However, hairy vetch cover cropping should be accompanied by an optimized fertilization, crop sequence and tillage management. Further studies are needed that monitor the long-term effect of green manuring on the soil status and its feasibility on a country scale.

Acknowledgements. We thank the Federal Ministry of Education and Research of Germany for funding the project "Restoration of degraded arable soils of Moldova using vetch as green manure" (FDK 01DK13008).

Edited by: A. Jordán

\section{References}

Abdul-Baki, A. A., Teasdale, J. R., Korcak, R., Chitwood, D. J., and Huettel, R. N.: Fresh-market tomato production in a low-input alternative system using cover-crop mulch, Hortscience, 31, 6569, 1996.

Andries, S., Cerbari, V., and Filipciuc, V.: The quality of moldovan soils: Issues and solutions, in: Soil as world heritage, edited by: Dent, D., Springer, Dordrecht, 9-15, 2014.

Balkcom, K. S., Arriaga, F. J., and van Santen, E.: Conservation systems to enhance soil carbon sequestration in the southeast u.S. Coastal plain, Soil Sci. Soc. Am. J., 77, 1774-1783, doi:10.2136/sssaj2013.01.0034, 2013.

Blanco-Canqui, H., Mikha, M. M., Presley, D. R., and Claassen, M. M.: Addition of cover crops enhances no-till potential for improving soil physical properties, Soil Sci. Soc. Am. J., 75, 14711482, doi:10.2136/sssaj2010.0430, 2011.

Boincean, B. P.: Fifty years of field experiments with crop rotations and continuous culltures at the selectia research institute for field crops in: Soil as world heritage, edited by: Dent, D., Springer, Dordrecht, 175-199, 2014.

Brandsaeter, L. O., Heggen, H., Riley, H., Stubhaug, E., and Henriksen, T. M.: Winter survival, biomass accumulation and $\mathrm{n}$ mineralization of winter annual and biennial legumes sown at various times of year in northern temperate regions, Eur. J. Agron., 28, 437-448, doi:10.1016/j.eja.2007.11.013, 2008.

Bremner, J. M.: Nitrogen-total, in: Methods of soil analysis, part 3 chemical methods, edited by: Sparks, D. L., Page, A. L., Helmke, P. A., Loeppert, R. H., Soltanpour, P. N., Tabatabai, M. A., Johnston, C. T., and Sumner, M. E., 5, Soil Science Society of America, Madison, 1085-1121, 1996. 
Bronick, C. J. and Lal, R.: Soil structure and management: A review, Geoderma, 124, 3-22, 2005.

Cherr, C. M., Scholberg, J. M. S., and McSorley, R.: Green manure approaches to crop production: A synthesis, Agron. J., 98, 302319, doi:10.2134/agronj2005.0035, 2006.

Clark, A.: Managing cover crops profitably, Sustainable Agriculture Network, Beltsville, 2007.

Cline, G. R. and Silvernail, A. F.: Residual nitrogen and kill date effects on winter cover crop growth and nitrogen content in a vegetable production system, HortTechnology, 11, 219-225, 2001.

Cook, J. C., Gallagher, R. S., Kaye, J. P., Lynch, J., and Bradley, B.: Optimizing vetch nitrogen production and corn nitrogen accumulation under no-till management, Agron. J., 102, 1491-1499, doi:10.2134/agronj2010.0165, 2010.

Dabney, S. M., Delgado, J. A., and Reeves, D. W.: Using winter cover crops to improve soil and water quality, Commun. Soil Sci. Plant Anal., 32, 1221-1250, 10.1081/css-100104110, 2001.

Dabney, S. M., Delgado, J. A., Meisinger, J. J., Schomberg, H. H., Liebig, M. A., Kaspar, T., Mitchell, J., and Reeves, W.: Using cover crops and cropping systems for nitrogen management, in: Advances in nitrogen management for water quality, edited by: Delgado, J. A. and Follett, R. F., Soil and Water Conservation Society, Ankeny, 230-281, 2010.

Eitzinger, J., Trnka, M., Semeradova, D., Thaler, S., Svobodova, E., Hlavinka, P., Siska, B., Takac, J., Malatinska, L., Novakova, M., Dubrovsky, M., and Zalud, Z.: Regional climate change impacts on agricultural crop production in central and eastern europe hotspots, regional differences and common trends, J. Agric. Sci., 151, 787-812, 2013.

Ellert, B. H. and Bettany, J. R.: Calculation of organic matter and nutrients stored in soils under contrasting management regimes, Can. J. Soil Sci., 75, 529-538, 1995.

Fageria, N. K., Baligar, V. C., and Bailey, B. A.: Role of cover crops in improving soil and row crop productivity, Commun. Soil Sci. Plant Anal., 36, 2733-2757, doi:10.1080/00103620500303939, 2005.

Fageria, N. K.: Green manuring in crop production, J. Plant Nutr., 30, 691-719, doi:10.1080/01904160701289529, 2007.

Garcia-Orenes, F., Roldan, A., Mataix-Solera, J., Cerda, A., Campoy, M., Arcenegui, V., and Caravaca, F.: Soil structural stability and erosion rates influenced by agricultural management practices in a semi-arid mediterranean agro-ecosystem, Soil Use Manage., 28, 571-579, doi:10.1111/j.1475-2743.2012.00451.x, 2012.

Gee, G. W., and Bauder, J. W.: Particle-size analysis, in: Methods of soil analysis, Part 1, physical and mineralogical methods, edited by: Page, A. L., 5, Soil Science Society of America, Wisconsin, 383-411, 1986.

Griffin, T., Liebman, M., and Jemison, J.: Cover crops for sweet corn production in a short-season environment, Agron. J., 92, 144-151, 2000.

Guldan, S. J., Martin, C. A., CuetoWong, J., and Steiner, R. L.: Dry-matter and nitrogen yields of legumes interseeded into sweet corn, Hortscience, 31, 206-208, 1996.

Gupta, V. V. S. R., and Germida, J. J.: Distribution of microbial biomass and its activity in different soil aggregate size classes as affected by cultivation, Soil Biol. Biochem., 20, 777-786, doi:10.1016/0038-0717(88)90082-x, 1988.
Hassink, J.: The capacity of soils to preserve organic c and $\mathrm{n}$ by their association with clay and silt particles, Plant Soil, 191, 7787, doi:10.1023/a:1004213929699, 1997.

Higashi, T., Yunghui, M., Komatsuzaki, M., Miura, S., Hirata, T., Araki, H., Kaneko, N., and Ohta, H.: Tillage and cover crop species affect soil organic carbon in andosol, kanto, japan, Soil Tillage Res., 138, 64-72, doi:10.1016/j.still.2013.12.010, 2014.

IUSS Working Group WRB: World reference base for soil resources 2006, World soil resources reports no. 103, fao, rome, in, 2006.

Jarecki, M. K. and Lal, R.: Crop management for soil carbon sequestration, Crit. Rev. Plant Sci., 22, 471-502, doi:10.1080/07352680390253179, 2003.

Jeon, W. T., Choi, B., Abd El-Azeem, S. A. M., and Ok, Y. S.: Effect of different seeding methods on green manure biomass, soil properties and rice yield in rice-based cropping systems, Afr. J. Biotechnol., 10, 2024-2031, 2011.

Krupenikov, I. A., Boincean, B. P., and Dent, D.: The black earth - ecological principles for sustainable agriculture on chernozem soils, Springer, Dordrecht, 2011.

Kuharuk, E., and Crivova, O.: The state of soil erosion in the republic of moldova and the need for monitoring in: Soil as world heritage, edited by: Dent, D., Springer, Dordrecht, 17-20, 2014.

Kuo, S., Sainju, U. M., and Jellum, E. J.: Winter cover crop effects on soil organic carbon and carbohydrate in soil, Soil Sci. Soc. Am. J., 61, 145-152, 1997.

Kuo, S., and Jellum, E. J.: Long-term winter cover cropping effects on corn (zea mays 1.) production and soil nitrogen availability, Biology and Fertility of Soils, 31, 470-477, doi:10.1007/s003740000193, 2000.

Mirsky, S. B., Ryan, M. R., Curran, W. S., Teasdale, J. R., Maul, J., Spargo, J. T., Moyer, J., Grantham, A. M., Weber, D., Way, T. R., and Camargo, G. G.: Conservation tillage issues: Cover crop-based organic rotational no-till grain production in the mid-atlantic region, USA, Renew. Agr. Food Syst., 27, 31-40, 10.1017/s1742170511000457, 2012.

Mischler, R., Duiker, S. W., Curran, W. S., and Wilson, D.: Hairy vetch management for no-till organic corn production, Agron. J., 102, 355-362, doi:10.2134/agronj2009.0183, 2010.

Nelson, D. W., and Sommers, L. E.: Total carbon, organic carbon, and organic matter, in: Methods of soil analysis, Part 3 - chemical methods, edited by: Sparks, D. L., Page, A. L., Helmke, P. A., Loeppert, R. H., Soltanpour, P. N., Tabatabai, M. A., Johnston, C. T., and Sumner, M. E., 5, Soil Science Society of America Madison, 961-1010, 1996.

Nichols, K. A., and Toro, M.: A whole soil stability index (wssi) for evaluating soil aggregation, Soil Tillage Res., 111, 99-104, 10.1016/j.still.2010.08.014, 2011.

Novara, A., Gristina, L., Saladino, S. S., Santoro, A., and Cerda, A.: Soil erosion assessment on tillage and alternative soil managements in a sicilian vineyard, Soil Tillage Res., 117, 140-147, doi:10.1016/j.still.2011.09.007, 2011.

Oades, J. M.: Soil organic matter and structural stability - mechanisms and implications for management, Plant Soil, 76, 319-337, 1984.

Poeplau, C., and Don, A.: Carbon sequestration in agricultural soils via cultivation of cover crops - a meta-analysis, Agric. Ecosyst. Environ., 200, 33-41, doi:10.1016/j.agee.2014.10.024, 2015. 
Post, W. M., Izaurralde, R. C., Mann, L. K., and Bliss, N.: Monitoring and verifying changes of organic carbon in soil, Clim. Change, 51, 73-99, 10.1023/a:1017514802028, 2001.

Puget, P., and Drinkwater, L. E.: Short-term dynamics of root- and shoot-derived carbon from a leguminous green manure, Soil Sci. Soc. Am. J., 65, 771-779, 2001.

Rochester, I., and Peoples, M.: Growing vetches (vicia villosa roth) in irrigated cotton systems: Inputs of fixed $n, n$ fertiliser savings and cotton productivity, Plant Soil, 271, 251-264, doi:10.1007/s11104-004-2621-1, 2005.

Sainju, U. M. and Singh, B. P.: Tillage, cover crop, and kill-planting date effects on corn yield and soil nitrogen, Agron. J., 93, 878886,2001

Sainju, U. M., Singh, B. P., and Whitehead, W. F.: Long-term effects of tillage, cover crops, and nitrogen fertilization on organic carbon and nitrogen concentrations in sandy loam soils in georgia, USA, Soil Tillage Res., 63, 167-179, doi:10.1016/s01671987(01)00244-6, 2002.

Sainju, U. M., Whitehead, W. F., and Singh, B. R.: Cover crops and nitrogen fertilization effects on soil aggregation and carbon and nitrogen pools, Can. J. Soil Sci., 83, 155-165, 2003.

Sainju, U. M., Whitehead, W. F., and Singh, B. P.: Biculture legumecereal cover crops for enhanced biomass yield and carbon and nitrogen, Agron. J., 97, 1403-1412, doi:10.2134/agronj2004.0274, 2005a.

Sainju, U. M., Whitehead, W. F., and Singh, B. P.: Carbon accumulation in cotton, sorghum, and underlying soil as influenced by tillage, cover crops, and nitrogen fertilization, Plant Soil, 273, 219-234, doi:10.1007/s11104-004-7611-9, 2005b.

Sainju, U. M.: Carbon and nitrogen pools in soil aggregates separated by dry and wet sieving methods, Soil Sci., 171, 937-949, doi:10.1097/01.ss0000228062.30958.5a, 2006.

Six, J., Paustian, K., Elliott, E. T., and Combrink, C.: Soil structure and organic matter: I. Distribution of aggregate-size classes and aggregate-associated carbon, Soil Sci. Soc. Am. J., 64, 681-689, 2000.

Six, J., Bossuyt, H., Degryze, S., and Denef, K.: A history of research on the link between (micro)aggregates, soil biota, and soil organic matter dynamics, Soil Tillage Res., 79, 7-31, doi:10.1016/j.still.2004.03.008, 2004.

Sollins, P., Homann, P., and Caldwell, B. A.: Stabilization and destabilization of soil organic matter: Mechanisms and controls, Geoderma, 74, 65-105, doi:10.1016/s0016-7061(96)00036-5, 1996.

Stavi, I., and Lal, R.: Agroforestry and biochar to offset climate change: A review, Agron. Sustain. Dev., 33, 81-96, doi:10.1007/s13593-012-0081-1, 2013.

Steffens, M., Kölbl, A., and Kögel-Knabner, I.: Alteration of soil organic matter pools and aggregation in semi-arid steppe topsoils as driven by organic matter input, Europ. J. Soil Sci., 60, 198212, 2009.

Supit, I., van Diepen, C. A., de Wit, A. J. W., Kabat, P., Baruth, B., and Ludwig, F.: Recent changes in the climatic yield potential of various crops in europe, Agric. Syst., 103, 683-694, doi:10.1016/j.agsy.2010.08.009, 2010.

Tarui, A., Matsumura, A., Asakura, S., Yamawaki, K., Hattori, R., and Daimon, H.: Evaluation of mixed cropping of oat and hairy vetch as green manure for succeeding corn production, Plant. Prod. Sci., 16, 383-392, 2013.
Teasdale, J. R., Devine, T. E., Mosjidis, J. A., Bellinder, R. R., and Beste, C. E.: Growth and development of hairy vetch cultivars in the northeastern united states as influenced by planting and harvesting date, Agron. J., 96, 1266-1271, 2004.

Tenopala, J., Gonzalez, F. J., and de la Barrera, E.: Physiological responses of the green manure, vicia sativa, to drought, Bot. Sci., 90, 305-311, 2012.

Tisdall, J. M. and Oades, J. M.: Organic matter and water-stable aggregates in soils, Journal of Soil Science, 33, 141-163, 1982.

Tonitto, C., David, M. B., and Drinkwater, L. E.: Replacing bare fallows with cover crops in fertilizer-intensive cropping systems: A meta-analysis of crop yield and n dynamics, Agric. Ecosyst. Environ., 112, 58-72, doi:10.1016/j.agee.2005.07.003, 2006.

Tosti, G., Benincasa, P., Farneselli, M., Tei, F., and Guiducci, M.: Barley-hairy vetch mixture as cover crop for green manuring and the mitigation of $\mathrm{n}$ leaching risk, Eur. J. Agron., 54, 34-39, doi:10.1016/j.eja.2013.11.012, 2014.

Trnka, M., Brazdil, R., Olesen, J. E., Eitzinger, J., Zahradnicek, P., Kocmankova, E., Dobrovolny, P., Stepanek, P., Mozny, M., Bartosova, L., Hlavinka, P., Semeradova, D., Valasek, H., Havlicek, M., Horakova, V., Fischer, M., and Zalud, Z.: Could the changes in regional crop yields be a pointer of climatic change?, Agric. For. Meteorol., 166, 62-71, doi:10.1016/j.agrformet.2012.05.020, 2012.

Unger, P. W. and Vigil, M. F.: Cover crop effects on soil water relationships, J. Soil Water Conserv., 53, 200-207, 1998.

Ursu, A., Overenco, A., Marcov, I., and Curcubat, S.: Chernozem: Soil of the steppe, in: Soil as world heritage, edited by: Dent, D., Springer, Dordrecht, 3-8, 2014.

Villamil, M. B., Bollero, G. A., Darmody, R. G., Simmons, F. W., and Bullock, D. G.: No-till corn/soybean systems including winter cover crops: Effects on soil properties, Soil Sci. Soc. Am. J., 70, 1936-1944, doi:10.2136/sssaj2005.0350, 2006.

von Lützow, M., Kögel-Knabner, I., Ekschmitt, K., Matzner, E., Guggenberger, G., Marschner, B., and Flessa, H.: Stabilization of organic matter in temperate soils: Mechanisms and their relevance under different soil conditions - a review, Europ. J. Soil Sci., 57, 426-445, doi:10.1111/j.1365-2389.2006.00809.x, 2006.

Vronskih, M. D.: Climate change and its impact on soil productivity in moldova in: Soil as world heritage, edited by: Dent, D. Springer, Dordrecht, 101-117, 2014.

Wiesmeier, M., Kreyling, O., Steffens, M., Schönbach, P., Wan, H. W., Gierus, M., Taube, F., Kölbl, A., and Kögel-Knabner, I.: Short-term degradation of semiarid grasslands - results from a controlled-grazing experiment in northern china, J. Plant Nutr. Soil Sci., 175, 434-442, doi:10.1002/jpln.201100327, 2012a.

Wiesmeier, M., Steffens, M., Mueller, C. W., Kölbl, A., Agnieszka, R., Peth, S., Horn, R., and Kögel-Knabner, I.: Aggregate stability and physical protection of soil organic carbon in semi-arid steppe soils, Europ. J. Soil Sci., 63, 22-31, 2012b.

Wiesmeier, M., von Lützow, M., Spörlein, P., Geuss, U., Hangen, E., Reischl, A., Schilling, B., and Kögel-Knabner, I.: Land use effects on organic carbon storage in soils of bavaria: The importance of soil types, Soil Tillage Res., 146, 296-302, doi:10.1016/j.still.2014.10.003, 2015.

Wortman, S. E., Francis, C. A., Bernards, M. L., Drijber, R. A., and Lindquist, J. L.: Optimizing cover crop benefits with diverse mixtures and an alternative termination method, Agron. J., 104, 1425-1435, doi:10.2134/agronj2012.0185, 2012. 
Zhu, X. Y., Liu, R. T., and Zhang, Y. J.: Interactions of a hairy vetchcorn rotation and $\mathrm{p}$ fertilizer on the npk balance in an upland red soil of the yunnan plateau, Afr. J. Biotechnol., 10, 9040-9050, 2011. 